\title{
EXPLORING PICTORIAL RUNES IN LUCA ENOCH'S COMIC BOOK SERIES GEA
}

\author{
UDC 741.5:81'37
}

\author{
Miloš Tasić ${ }^{1}$, Dušan Stamenković ${ }^{2}$ \\ ${ }^{1}$ University of Niš, Faculty of Mechanical Engineering, Niš, Serbia \\ ${ }^{2}$ University of Niš, Faculty of Philosophy and Center for Cognitive Sciences, Niš, Serbia
}

\begin{abstract}
Drawing on the work of Forceville (2005, 2006, 2011), who employed linguistic tools in analysing comics, the paper deals with pictorial runes as a specific type of visual information found in comic books. As Kennedy (1982) proposes, pictorial runes are graphic devices used in pictures to modify the literal depictions of objects, intended to convey certain aspects of those objects that are otherwise difficult to depict literally. In comics, they are usually employed to imply various emotions, such as anger, fear, pain, or surprise, and indicate speed or the direction of a moving object, among other things. Using the research model presented by Forceville (2011), the paper aims at identifying and categorising pictorial runes in a popular Italian comic book series Gea, in an attempt to corroborate the above method and add to the list of already inventoried runes. Furthermore, the new runes found in this comic book series show evidence of being indexical, rather than symbolic, signs. The paper also briefly outlines the distribution of runes across the entire series.
\end{abstract}

Key words: pictorial runes, visual language, comics studies, rune catalogue, metaphor, metonymy

\section{INTRODUCTION}

Given the emerging number of studies that relate principles that govern our understanding of verbal languages to those underlying visual languages in comics, our intention was to tackle one of the phenomena that illustrate these principles - the notion of pictorial runes. By definition, pictorial runes are simple, abstract graphic additions to literal object depictions, which carry almost no inherent meaning themselves, yet serve the purpose of conveying supplementary meaning. Examples of pictorial runes are jagged lines around a thumb hit by a hammer suggesting pain, spirals around someone's head to suggest dizziness, or lines adjacent to one's body suggesting motion. With this in mind, the current

Submitted May $15^{\text {th }} 2017$, accepted for publication November $27^{\text {th }}, 2017$

Corresponding author: Dušan Stamenković

Faculty of Philosophy, Ćirila i Metodija 2, 18000 Niš, Serbia

E-mail: dusan.stamenkovic@filfak.ni.ac.rs 
study aims to propose some additions and revisions to the first catalogue of pictorial runes compiled by Forceville (e.g. 2005, 2011). For this purpose, we used a comic book series belonging to the tradition of Italian comics, or fummeti, which has not so far been analysed in this context, unlike Franco-Belgian, American and Japanese comics. The study will try to prove that including other comics drawing traditions might allow us to see different elements that can be classified as runes and provide a fresh perspective on the issue at hand. Drawing on the work of Charles Forceville $(2005,2006,2008,2011)$ and Neil Cohn (Cohn 2007, 2012a, 2013; Cohn and Ehly 2016), our study deals with pictorial runes as a specific type of visual information or visual lexicon found in comic books. The paper will employ Forceville's methodology developed in his 2011 paper entitled "Pictorial runes in Tintin and the Picaros".

\subsection{Visual languages in comics}

Various elements of comic books have been studied in Europe since as early as the 1970s (e.g. Gubern 1972; Hünig 1974; Koch 1971), and these studies largely relied on the structuralist tradition and had a semiological perspective. However, it was not until the first in the trilogy of Will Eisner's instructional books, Comics and Sequential Art, which came out in 1985, that serious academic research was directed towards examining this medium. What Eisner set out to do was to define comics as a form of reading, and an art that possesses and communicates in its own language, whose disciplined application "creates the 'grammar' of sequential art" (Eisner 1985/2008: 2). This notion was further expanded and examined in detail by Cohn as we will see below. On the other hand, Scott McCloud's Understanding Comics in 1993, influenced various comics studies in both the USA and the UK, and authors such as Saraceni (2000, 2003), Stainbrook (2003), Bridgeman (2005), Lim (2006), etc.

Perhaps the most comprehensive approach to visual language in comics can be found in the works of Cohn (e.g. 2003, 2007, 2010, 2012a, 2012b, 2013). Cohn (2013: 3-7) explains that structured sequential images literally become visual languages in the similar way in which structured sequential sounds become spoken languages and in which structured hand and body motions become sign languages. He claims that visual languages can be on par with the former two types, due to the fact that they possess the primary components that underlie the structure of all of them (modality, meaning and grammar), at the same time being systematic and combinatorial. As we can talk about different verbal and sign languages, we can also talk about different visual languages of comics as well - Cohn (2013: 137-194) provides accounts of the American, Japanese and Central Australian visual languages and mentions a number of European comics belonging to different traditions. In this sense, we may say that our study is directed at the Italian visual language. In his proposal of future research in the field of "visual linguistics," Cohn (2012a: 92-118) mentions that we may involve all the traditional areas of linguistic inquiry, including "graphemics, photology (visual-graphic analogues to phonetics and phonology), morphology, semantics, grammar as well as multimodality and acquisition." Within the study of morphology in visual languages, Cohn (2013: 23-49) gives a survey of the open-class and the closed-class "lexical" items, and our study ought to describe a subset of this class of visual items. 


\subsection{Pictorial metaphors and runes}

Before starting his corpus investigation of pictorial runes, Forceville had dealt with a number of issues related to pictorial metaphors, as a part of his "multimodal metaphor" approach (e.g. Forceville 1994, 1996, 2005, 2006; Forceville and Urios-Aparisi 2009), where pictorial metaphors were viewed as sharing many features with their linguistic counterparts - their conventional readings did not exhaust their meaning potential, they had two distinctive terms, one the primary subject or tenor, the other the secondary subject or vehicle, which usually seemed to be non-reversible and relied upon taking various contextual levels into consideration (Forceville 1996: 64-65). Although they share some features of linguistic metaphors, we can frequently find pictorial metaphors that have no clear equivalent in language. This becomes even more frequent with another type of pictorial device - the pictorial rune, defined as "a graphic device used in a picture which is a modification of the literal depiction of an object, making some aspect of the object become easy to depict, that aspect of the object often being difficult for the literal depiction to convey" (Kennedy 1982: $600)$. Thus, in comics, pictorial runes are usually very simple, abstract graphic additions, with almost no inherent meaning, yet fulfilling the purpose of conveying supplementary meaning. The elements that Kennedy and Forceville call pictorial runes have also been studied by Walker (1980) and Cohn (2007), among others, though they do not share their terminology. Given their dependence on other types of information, runes could be metaphorically seen as graphic equivalents of what in language are bound morphemes (Engelhardt 2002: 24; Forceville 2011: 877).

Forceville's approach (for a more detailed description, see Stamenković and Tasić 2014 ) is based on the assumption that visual metaphors and metonymies stand equal with their verbal counterparts in the light of conceptual metaphor theory and the embodied cognition thesis (e.g., Gibbs, Jr. 2006; Kövecses 2010; Johnson 1987; Lakoff 1987, 1993; Lakoff and Johnson 1980; Sweetser 1991). Forceville and Urios-Aparisi (2009: 4) claim that "[...] if researching non-verbal and not-purely-verbal metaphor does not yield robust findings, this jeopardizes the Lakoff-and-Johnsonian presupposition that we think metaphorically." Having in mind Forceville's claim that, in the light of embodied cognition, researching runes and other visual elements might reveal some aspects of our conceptualization and that their scope goes beyond language (Forceville 2011: 876), it is easy to understand Bounegru's and Forceville's idea that "[...] further assessment [of CMT] requires that analyses are extended from mere verbal discourse [...] to pictorial and multimodal discourse [...]" (Bounegru and Forceville 2011: 209-210).

Forceville started his 2011 study of pictorial runes with four main aims: to contribute to the historiography and theorisation of the comics genre, to increase our insight into the possibilities of pictorial communication, to deal with the broader question how visual information can be used to communicate non-literally, and to check whether runes may tell us something about how we think (Forceville 2011: 875-876). Forceville's study was the first one to tackle the issue of runes more thoroughly, though he refers to a number of sources which had mentioned runes in passing (e.g., Tan 2001; Saraceni 2003; McCloud 2006). Apart from his 2005 and 2011 papers, several other studies employ the term pictorial rune to refer to the same phenomenon (Bateman and Wildfeuer, 2014; Ojha, Forceville and Indurkhya, 2013), or partially cover some rune-related issues (e.g., Eerden 2009; Shinohara and Matsunaka 2009; Van Eunen 2007), though their main goal is not to enrich Forceville's rune catalogue. Forceville recognizes pictorial runes as "very simple, abstract-looking flourishes, which 
would have little meaning if we were to encounter them in isolated, decontextualized form" and distinguishes them from the so-called pictograms (e.g. skulls, lightning, flames, stars, flowers, etc.), which had previously been dubbed "metáforas visuals e ideograms" by Gasca and Gubern (2001: 312ff). Pictograms usually denote emotional and physical states in a nonliteral way, but they do have some inherent meaning due to their mimetic character (Forceville 2011: 876).

Within Cohn's paradigm (2013), both pictorial runes and pictograms would clearly be classified as belonging to the closed-class visual items in our visual lexicons - along with carriers (speech balloons and bubbles), eye-umlauts, action stars and fight clouds, suppletion and reduplication, Cohn mentions indexical lines (divided into path and deictic lines) and impact stars, both of which have the properties of Forceville's pictorial runes, as well as upfixes, which largely correspond to pictograms in Forceville's terminology. Cohn (2013: 38-39) concludes that the most common type of indexical lines are motion lines belonging to the closed-class "morphemes," they have to be attached to a root morpheme in order to express motion. Cohn and Maher (2015) provide a summary of numerous studies on the psychology of motion lines, claiming that motion lines are conventionally understood. According to McCloud (1993: 108-110), motion lines were a response to the problem of showing movements in comics as a static medium, along with multiple images and streaking. Though the beginning of the line ought to denote the point from which the object starts moving and the end of the line marks the point to, the whole concept of expressing motion by means of lines can be related to the phenomenon of fictive motion in verbal languages. Cohn (2013: 109) claims that they become more understood as people age, and their presence "helps facilitate memory and comprehension for [still] images of moving objects." Other types of indexical lines in Cohn's (2013: 39-40) classification include scopic lines (which show the path of one's vision) and radial and impact lines (showing a path which radiates away from the root object). On the other hand, deictic lines simply point at something or draw attention to something. Along with these, impact stars (Cohn 2013: 41) show the impact of one object with another and they are sometimes combined with motion and impact lines. Finally, the majority of Cohn's upfixes (2013: 42-43) could be classified as pictograms, as they use small icons (of hearts, cogs, light bulbs, clouds) to show emotional and cognitive states. Among these we find the graphic representation of drunkenness, which is not iconic, does not seem to have any kind of inherent meaning and would thus probably belong to pictorial runes.

Forceville (2011: 876-877) states that pictorial runes reveal their meaning when combined "with one or more of the following: (1) other runes; (2) pictograms; (3) balloonic features; (4) iconic information, including facial expressions and hand/arm postures; (5) panel form, lay-out and orientation; and (6) verbal text." By answering a set of questions (e.g. Is something to be considered a rune, or a literal depiction?; What is a rune's prototypical form, location or orientation?; Does a rune prototypically occur on its own, or as a multiple? With what other runes can a given rune occur?), Forceville outlined a model for rune naming, description and classification which allowed him to perform an analysis of the runes present in Tintin and the Picaros. He eventually concluded that pictorial runes "constitute a rudimentary 'language' that is used to (help) visualize non-visible events and experiences understood to take place, or to have taken place, in a static medium" (Forceville 2011: 888), to submit that pictorial runes are non-literal representations that convey movement and emotions in the medium of comics (Forceville 2011: 887), and to propose a number of potential study directions when it comes to investigating runes: 
developing computer programs which would facilitate rune analysis, tracing the diachronic development of runes and performing other empirical procedures (Forceville 2011: 888). This is where our study takes off. By means of an empirical approach, we will try to expand on Forceville's explorations in at least two directions: (1) to suggest some additions and revisions of the rune catalogue proposed in Forceville (2011) and thus enrich it and (2) to examine the development of pictorial runes in a whole series of comic books, with regard to their frequency, type and position.

It should be noted here that Cohn's and Forceville's terminologies differ in the sense that Cohn's descriptions are more abstract, whereas Forceville's reflect more surfacerelated features. As we are dealing with a corpus study directed at different tokens, we have decided to follow Forceville's guidelines for this paper's purposes, though we do not deny the relevance of Cohn's terms.

\subsection{Rune catalogue}

The initial rune catalogue, proposed in "Pictorial runes in Tintin and the Picaros", consists of the total of six different runic types (plus special cases). The types include: speed lines, movement lines, droplets, spikes, spirals, twirls, and their appearance, position and function are defined in the following manner (Forceville 2011: 877-883): (a) speed lines (Forceville's schematization: $\cdots$ ) are straight or curved lines of various length, which appear behind or parallel to a person or object and indicate movement in a direction with a certain velocity; (b) movement lines (I多) are slightly curved and short lines, which have various orientations, they appear around or parallel to a body part or other object and indicate motion; (c) droplets $\left(0^{\circ} \mathrm{O}\right)$ appear in multiples in a halo-like fashion around a person's head; though they can have a mimetic meaning (denoting small portions of liquid), they can suggest that someone is emotionally affected: (d) spikes $(\mathrm{I} / /$, ) are circles or semi-circles of straight lines drawn around something, which appear in multiples in a halo-like fashion around a person's head or other object and either denote generic affect, enhance a sound which is produced or draw attention to a nonconspicuous salient item; (e) spirals $\left(\psi_{h}\right)$ are corkscrew-like flourishes which usually appear in multiples in a halo-like fashion around a person's head and convey a generically negative emotion; (f) twirls $\left(\xi_{\mathfrak{e}}\right)$ resemble spirals, but they are broader and have at least one open loop, they appear single, horizontally behind an agent or vertically above a person's head, indicating movement, the direction from which the agent has come or dizziness, drunkenness, confusion, or unconsciousness (Forceville 2011: 877883). Forceville (2011: 883) also allows for the existence of additional, special cases, such as smell lines or spirals with 'negativity' as their meaning, but at the same time concludes that the majority of the runes which he found in Picaros were accounted for by the six presented categories.

When classifying runes, Forceville faced a number of methodological considerations: (1) the question of whether we are dealing with a rune or a literal depiction; (2) the rune's form; (3) the rune's localization and orientation; (4) whether the rune appears as single or in multiples; (5) how the rune gets combined with other graphic and/or textual elements. All these considerations will be integrated into our study, in the attempt to achieve the two goals we have set.

Along the lines of the existence of many visual languages of comics (Cohn 2013), our attempt to "enrich" Forceville's catalogue might be classified as a contrastive analysis of 
morphological elements within these specific instances of the Italian and the Franco-Belgian visual languages. Adding these elements of Enoch's "idiolect" might be seen as a step towards creating a more complete catalogue of pictorial runes found in European comics.

\section{STUDY DESIGN}

\subsection{Corpus}

With regard to the attempt to enrich Forceville's 2011 rune catalogue, we have decided to analyse a comic book series belonging to another comic book tradition (i.e. non-FrancoBelgian). Therefore, the corpus consists of 18 volumes of the Italian comic book series Gea, created solely by Luca Enoch and originally published by one of the leading comics publishers in Italy, "Sergio Bonelli Editore". The Serbian version used in this study is licensed and published by the largest Serbian comics publishing house "Darkwood". Gea is a coming-of-age story starring the titular character, a teenage girl who guards the Earth against various adversities from other worlds and dimensions, which present a constant threat to the planet's population. The corpus involved the total of 9617 panels.

\subsection{Methodology}

We recorded all instances of pictorial runes in line with Forceville's (2011) methodology, taking into consideration their form, location, orientation, number, and co-occurrence. Apart from the six types of pictorial runes identified by Forceville (and their varieties in our corpus), we observed five additional types, and attempted to prove that they are also motivated, and not arbitrary signs (i.e. indices, and not symbols, in Peircean terms). The examples illustrated or mentioned in the paper are designated by three numbers, e.g. 7.42.3, where the first denotes the volume, the second the page, and the third the respective panel on that page that contains the rune in question.

\section{RESULTS AND DISCUSSION}

The aim of this section is to offer an extended catalogue of pictorial runes based on Forceville's classification. This will include the number and percentages of runes used in all volumes of the series as well. The section will also provide a brief examination of the distribution of the observed runic types in each separate volume.

\subsection{Rune coding, classification, and new runes}

Our catalogue draws on and expands the classification provided by Forceville (2011) in his paper on pictorial runes in Tintin and the Picaros. The first seven types listed here contain the six types observed by Forceville, plus one new runic type (trajectory lines), positioned there due to its connectedness with one of the original types. One of these Forceville's types also contains a new sub-category. These are then followed by four more new types that we have found in our corpus analysis. Each type will be adequately coded according to its appearance, variation, meaning, motivation, and use. 


\subsubsection{Speed lines}

In contrast to the speed lines found and described by Forceville, the speed lines in Gea look differently and are most often straight and very long (usually reaching the panel border), although there are cases where these lines are slightly curved to better represent the trajectory of the rapid movement drawn by the artist. However, they retain the same purpose, and that is to show that a person or an object is travelling at a speed much greater than the usual (Fig. 1, 1.18.3). They always appear in multiples, usually behind but sometimes even in front of a moving person or object. The meaning of the speed lines can also imply a certain extraordinary force exerted by a moving person or object (such as in 4.20.1), and there are even instances where speed lines become an integral part of a moving person or object (e.g. "speeding shadows", 11.44.2). The total number of panels containing speed lines in all 18 volumes was 500 (5.20\% of the corpus).

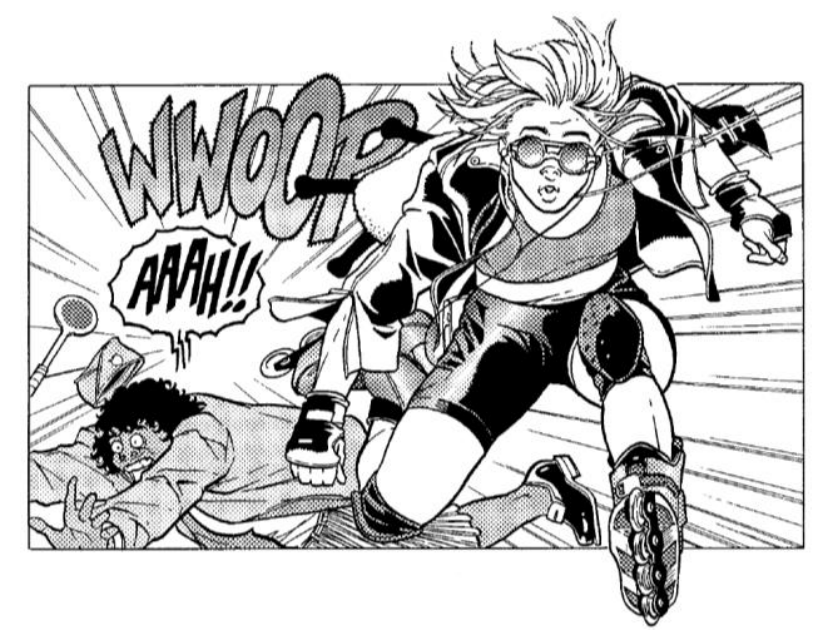

Fig. 1 Speed lines, Gea 1: Zaštitnica @ 2010 Luca Enoch/Sergio Bonelli Editore

Whereas some (e.g. Burr 2000) believe that these lines are embodied and based on our schematic experience, and that as such they represent signs which are motivated by our experience of motion streaks, there are also those who found that they are conventional and modulated by comic reading experience (Cohn and Maher 2015). Similarly to the speed lines in Tintin, these pictorial runes represent metonymical expressions necessary to convey the sense of speed in the static medium of comics.

\subsubsection{Movement lines}

The movement lines in Gea fully correspond to the ones described by Forceville. These are usually drawn around a certain body part or an object which is moving at a normal speed, or, perhaps, trembling. The majority consist of two or three straight or slightly curved parallel lines that follow the outer edge of the moving body part or object (Fig. 2, 14.9.2). Furthermore, there are instances of movement lines, even though far less present in the Gea series, which indicate different types of movement, e.g. turning (1.62.5) or rotation (1.15.1). These runes also appear in sets of two or three parallel lines, 
only curved in the appropriate direction. There were 2674 panels with movement lines in the series (27.80\% as viewed against the whole corpus).

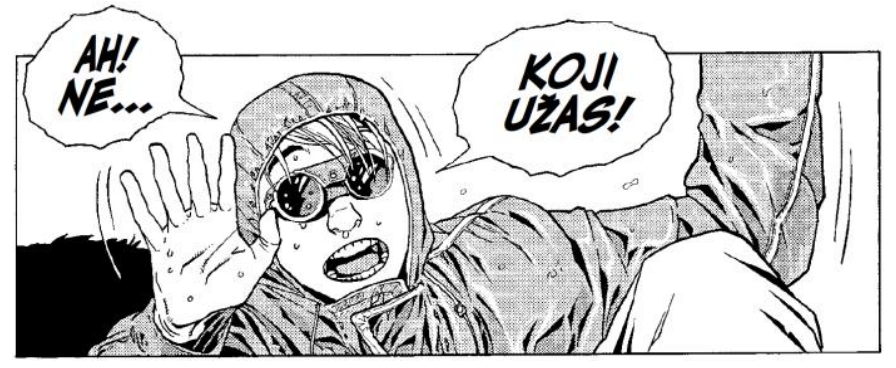

Fig. 2 Movement lines, Gea 14: Pad kapije (C) 2011 Luca Enoch/Sergio Bonelli Editore

They present movements of people's body parts or objects in, it seems, the only possible manner when it comes to the static graphic imagery found in comics. This is also corroborated by the sheer number of movement lines in the analysed comic book series, where they are by far the most frequently used of all pictorial runes.

\subsubsection{Trajectory lines}

Enoch employs yet another type of lines in Gea to depict more complicated movements that have occurred over a relatively longer period (Fig. 3, 2.57.4). The number of panels with trajectory lines was $81(0.84 \%)$.

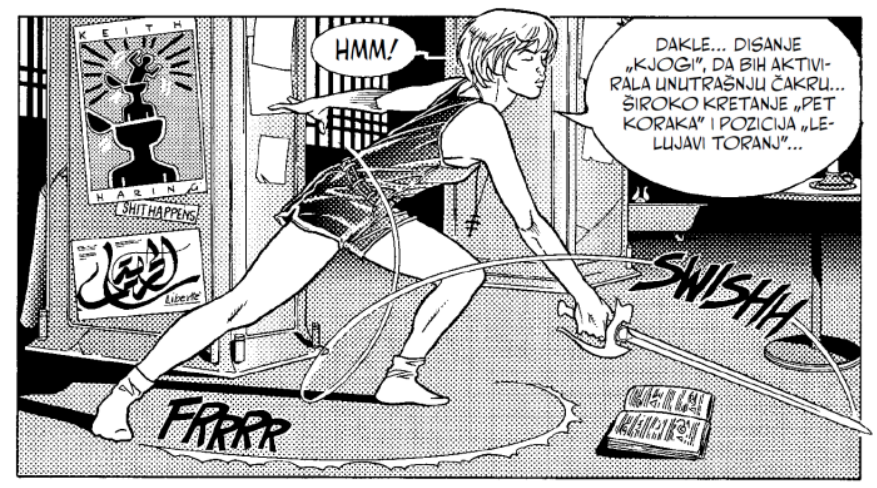

Fig. 3 Trajectory lines, Gea 2: Dionisova povorka @ 2010 Luca Enoch/Sergio Bonelli Editore

These complex lines are most often long, curving white lines on a black background, and the artist uses them to evoke the entire trajectory that a person's body part, or an object has travelled from the starting position to the one presented in the panel. Such lines are, naturally, not drawn parallel to whatever is moving, but so as to represent the travelled path. Even though trajectory lines share their purpose with movement lines, and that is to indicate motion, we have decided to include them here as a separate type, somewhat similar in their nature to what Potch and Williams (2012) call "ribbon paths". 


\subsubsection{Droplets}

As shown by Forceville in his analysis (2011: 879), droplets appear in Gea in the same manner, both with the literal, mimetic meaning, as small units of some liquid (e.g. as sweat on Gea's face, 3.10.1 or 3.41.2), and as runes intended to convey a different meaning, most often a specific emotional state of a character. Such droplets appear in multiples around a person's head in a halo-like fashion, and coupled with appropriate facial expressions they indicate various emotions such as anxiety, anger, surprise, shame, fear, etc. In Gea they are also used to emphasise a number of different emotions, predominantly negative of painful feelings, such as anxiety and anger (e.g. 1.58.2), surprise and shame (e.g. 5.51.4), fright (e.g. 2.64.4), or other types of discomfort (Fig. 4, 7.5.4). We found 132 panels that had droplets in them, which represented $1.37 \%$ of the total number of analysed panels.

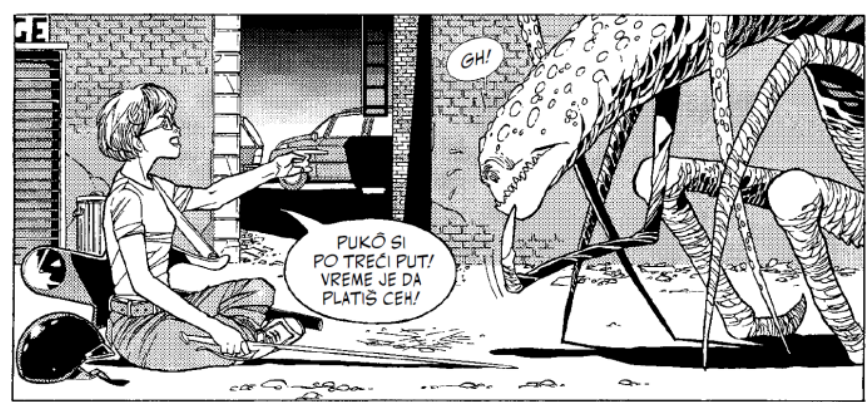

Fig. 4 Droplets, Gea 7: Klajvov krst @ 2010 Luca Enoch/Sergio Bonelli Editore

Our analysis of this pictorial rune confirms Forceville's statement (2011: 879) that droplets play the role of a metonymic extension of a given emotion, since they stand for the emotion itself in this case, even though they are actually only an accessory to the emotion being depicted in the visual language of comics. The emphasis here should be on the reason that might lie behind the use of droplets as metonymies in order to depict these types of emotions. In $\mathrm{Gea}$, at least, droplets exclusively follow those emotions that are experienced in some sort of a psychological or physical discomfort (barring physical exertion which leads to the literal use of droplets), even though some of them do not have an experiential basis for it, such as surprise, for example (Forceville 2011: 879). However, since sweating is associated with discomfort in such cases, we can easily understand the motivation behind this hyperbolic use of droplets across a variety of emotions in question, and not discard it as arbitrary.

\subsubsection{Spikes}

Spikes in Gea appear either as droplets do, in a halo-like fashion around a person's head, or in a circle, representing the source of a sound, usually accompanied by onomatopoeic expressions. The first type of spikes is almost identical in meaning to droplets, in that they indicate certain emotions, and there is no need to further explain them here. The second type (Fig. 5, 2.6.1), on the other hand, has a different motivation, and we believe that Forceville's explanation (2011: 888) hits home completely. Spikes drawn for the latter purpose are, most probably, related to our conceptualisation of sound as something radially emanating from its source, and this can be applied to our analysis as well. The artist uses spikes to show the specific place at which sound waves originate and from which they 
spread in all directions. As we will see later on, Enoch, the author of the comics series, elaborates on this by employing a different type of runes to indicate loud, sharp sounds. There were 34 panels with the first type of spikes $(0.35 \%)$ and 104 panels with the second type (1.08\% of the total number of panels).

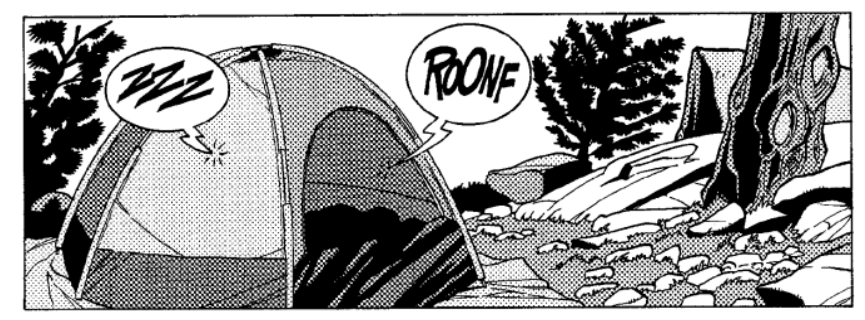

Fig. 5 Spikes, Gea 2: Dionisova povorka @ 2010 Luca Enoch/Sergio Bonelli Editore

\subsubsection{Discontinuous spikes}

As an expansion to the original catalogue, we have found a subtype of spikes, and called them discontinuous spikes. Similar to "regular" spikes, these appear in multiples around a person's head as well, but have a break or two in their continuity, that is, consist of one longer and one or two shorter lines (Fig. 6, 2.17.3). Coupled with adequate facial expressions, these runes are used to indicate various extreme emotions such as anger, rage, frustration, etc. If compared to "regular" spikes, they can be said to present augmented emotions, where the discontinuous or "broken" look of the spikes is presumably used to indicate the greater intensity of the expressed emotion. As with droplets and "regular" spikes found in Gea, discontinuous spikes also represent metonymic extensions of certain emotions, such as surprise, frustration, shame, etc. Moreover, analogous to the difference in the intensity of the emotion expressed by "regular" and discontinuous spikes, the latter are sometimes used to indicate sounds louder than those usually indicated by the former. We identified 38 panels with the first type of discontinuous spikes $(0.40 \%)$ and 36 panels with the second type $(0.37 \%$ of the total number of panels across all volumes).

\subsubsection{Spirals}

Even though Forceville mentions a suggestion of one of his anonymous reviewers, who proposes that the label of this type should be changed from spirals into waves due to the fact that the pictorial rune in question "would connote "waves of sound, pain, anger" (Forceville 2011: 888, footnote), we have decided to retain his terminology for the sake of avoiding a terminological confusion. In our analysis, Forceville's spirals do, indeed, resemble waves more, and the fact that the same pictorial runes are also used to indicate certain sounds, usually accompanied by notes or textual hints, seems to further endorse the above suggestion.

The spirals in Gea are primarily employed to convey negative emotions, to a certain extent similarly to droplets and spikes, and the artist also draws them in multiples around a person's head in a halo-like fashion (Fig. 7, 5.11.4). Gea spirals, however, differ slightly from Tintin spirals in that they have one or two dots at one of their ends, either the one closer to a person's head or the one farther away. We believe that this is simply a matter of Enoch's graphic style. Furthermore, as already mentioned above, on a couple of occasions, spirals are also used to indicate certain sounds, e.g. groaning or growling, and are then drawn in a circle or semi- 
circle around the source of the sound, similarly to the way spikes are themselves used to represent sounds. The investigation yielded 58 instances of panels with spirals representing emotions $(0.60 \%)$, but only three examples of spirals indicating sound $(0.03 \%)$.

\subsubsection{Twirl}

The manner in which Enoch draws the twirl in his comic book series, and the fact that it is never used to indicate anything else other than the physical and mental states such as dizziness, puzzledness, confusion, etc., differs from the twirl in Tintin, which is employed by Hergé to show specific types of movement as well, for example. As such, a twirl almost always appears on its own (we have found only one instance where three twirls were drawn around Gea's head, 7.28.4), most often above a person's head seen either from a vertical (2D) or horizontal (3D) perspective. However, the twirl is one of the runes that Enoch employs most freely, even putting it in a speech balloon (6.31.2) or using it as a balloon's tail (Fig. 8, 4.43.3). The artist uses twirls to depict all sorts of states that involve some kind of a spinning sensation or the feeling of being lost in "twirling" thoughts, thus this can easily be understood as the reason why they are employed in this specific manner. The twirl was found in 56 panels or $0.58 \%$ of the total number of panels.

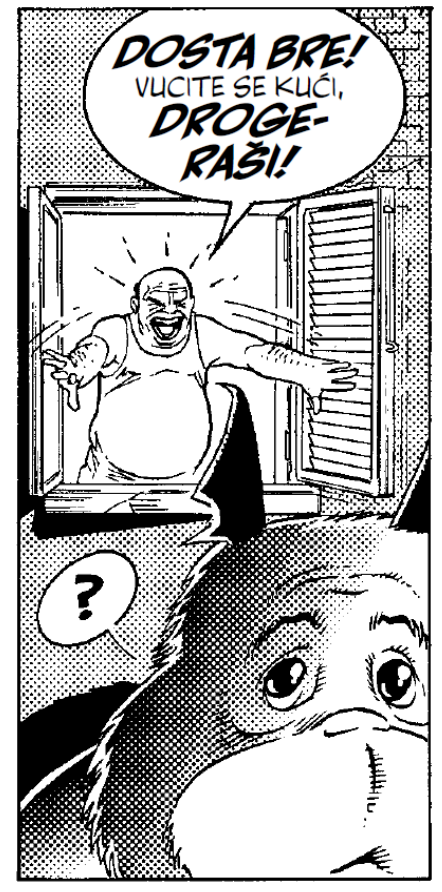

Fig. 6 Discontinuous spikes, Gea 2: Dionisova povorka @ 2010 Luca Enoch/Sergio Bonelli Editore

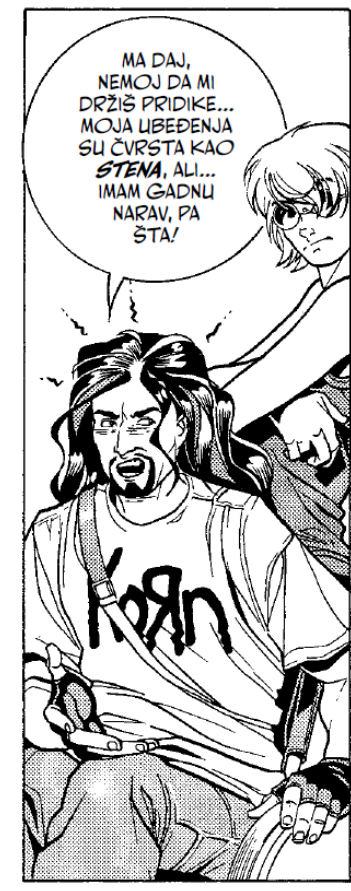

Fig. 7 Spirals, Gea 5: Nerov put (C) 2010 Luca Enoch/Sergio Bonelli Editore

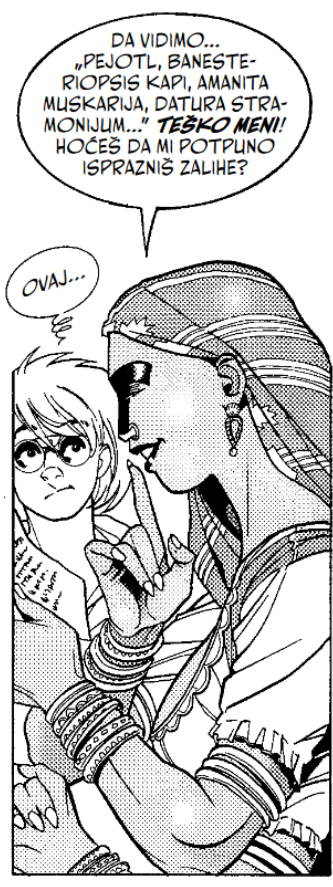

Fig. 8 Twirl, Gea 4: Majka nasilja (C) 2010 Luca Enoch/Sergio Bonelli Editore 


\subsubsection{Zoom lines}

In the analysis of Tintin and the Picaros, Forceville shows how spikes are used to draw attention to certain occurrences or people in the panels. In Gea, there are graphic tools that are also used to the same end. However, we believe that they should be classified within their own type based on the following two reasons. The first is that zoom lines do not exactly look like any other type of runes found in this comics series. Their appearance is somewhere between speed lines, in that they are long and straight, usually reaching the border of the panel, and spikes, in the manner that they are drawn around a point of interest, yet they can still be easily distinguished from the two (Fig. 9, 13.6.5). Second, they have a highly specified use, which spikes do not have here as is the case in Forceville's analysis, and that is to draw our attention to a specific facial expression, object, or any other type of information that needs to be made extra salient in the given moment. Zoom lines can be comprehended as the tracks along which we zoom in on what might otherwise remain unnoticed or which needs to be emphasized even further than as observed at a first glance. We managed to find 104 panels with zoom lines in the entire series (1.08\%).

\subsubsection{Lightning bolts (and discontinuous lightning bolts)}

The pictorial rune which resembles a lightning bolt appears more or less regularly in Gea, with the exclusive aim to indicate a loud, sharp or crackling sound, or even shouting on few occasions. It could be said that this rune type resembles what Cohn would call radial lines, only with a specific visual representation for sound. In Gea, lightning bolts are never used to convey emotions or anything else other than certain types of sounds, unlike the pictorial runes that possess this twofold purpose in this comic book series such as spikes or spirals. Lightning bolts appear single or in multiples around a source of a strong, highpitched, or piercing sound, usually coupled with some sort of text which denotes these types of sound, intensifying their salience (Fig. 10, 2.48.1). There are also instances of lightning bolts with breaks in the line at one of the ends (e.g. 1.69.2), similar to discontinuous spikes, but since this stylistic difference bears no change in the meaning of the pictorial rune, we have decided not to introduce them as a subtype of "regular" lightning bolts. All in all, there were 24 panels with this type of rune $(0.25 \%$ of the total number of panels).

Having in mind that this analysis is firmly based on Forceville's work, lightning bolts are the most problematic of the runes found in Gea. According to Forceville (2011: 876), lightning belongs to the group of pictograms (together with stars, skulls, flames, etc.), since its mimetic character carries some inherent meaning, thus disqualifying it from being considered as a pictorial rune. However, the manner in which lightning bolts are used by the artist in Gea shows no direct connection to the meaning of lightning or thunder most frequently used in comics, i.e. related to a strong light or electricity, or metaphorically to certain tumultuous emotions, leading us to believe that lightning bolts are here employed with a substantial level of abstraction, perhaps similar to droplets, therefore, eligible to be categorized as pictorial runes. Lightning bolts clearly represent metonymic extensions of sources of loud sound, just as spikes or spirals do in their own right, and they are, indeed, primarily associated with our conceptualisation of thunder, yet the catalogue of sounds indicated by lightning bolts is much richer than that. The way in which lightning bolts are drawn, with a sharp "chicane" in the middle, and positioned similarly to more often used spikes and spirals, is what is here intended to facilitate the readers' comprehension of specific, as already mentioned usually sharp or piercing, sounds. Our opinion is that the 
usage of this pictorial rune has nothing to do with it being a mere graphic simplification of what a real lightning looks like.

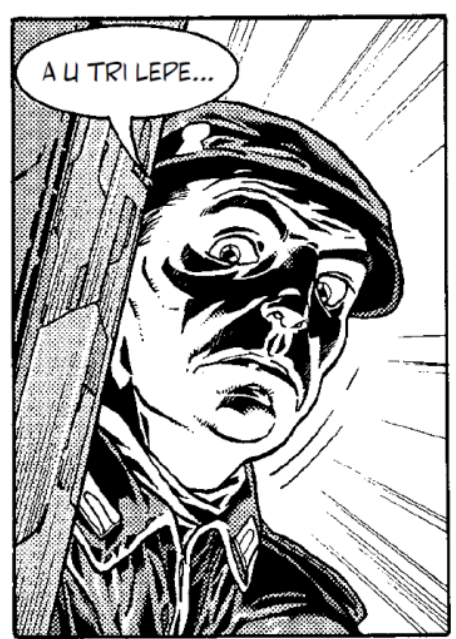

Fig. 9 Zoom lines, Gea 13 -

Pucanje pečata @ 2010 Luca

Enoch/Sergio Bonelli Editore

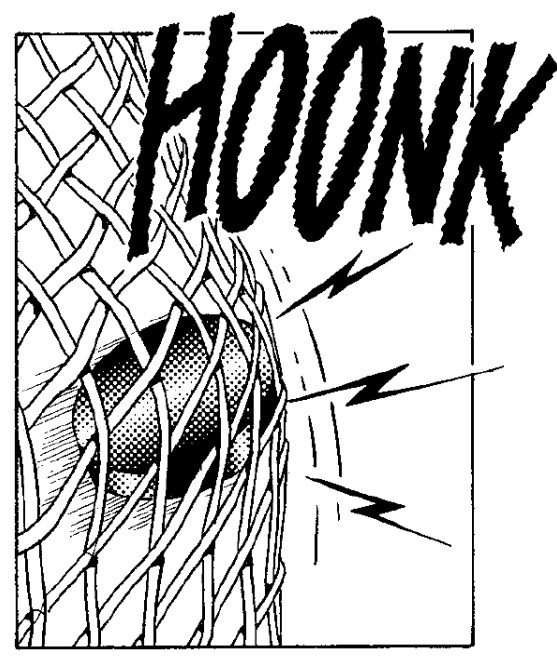

Fig. 10 Lightning bolts, Gea 2 Dionisova povorka (C) 2010 Luca Enoch/Sergio Bonelli Editore

\subsubsection{Impact star}

Despite the fact that our study is based on Forceville's terminology, this category of runes has been named in accordance with what Cohn calls "impact stars", as the term fits the category perfectly. In Gea, impact stars appear as six or eight-pointed stars with a small circular centre, exclusively used to indicate the focal point of pain inflicted by a strong blow. The artist usually draws them on the face or head of a person being struck, and the centre, we suppose, represents the spot from which pain spreads equally in all directions after the contact, i.e. the blow or shot (Fig. 11, 17.28.2). The entire series contains 28 panels with impact stars or $0.29 \%$.

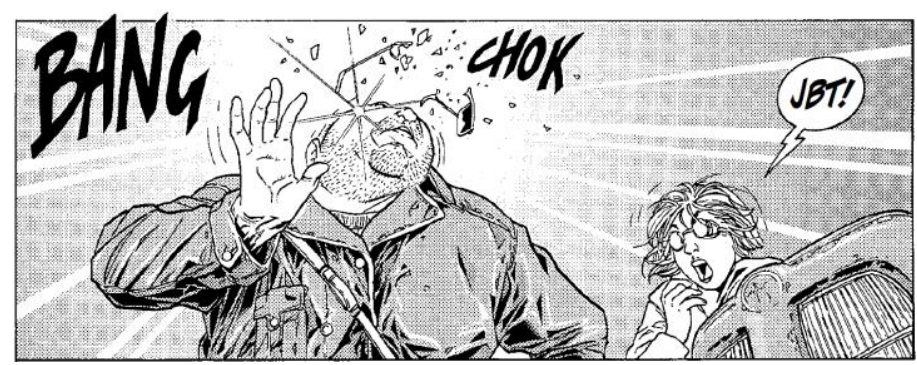

Fig. 11 Impact star, Gea 17: Doba surovosti @ 2011 Luca Enoch/Sergio Bonelli Editore 
This characteristic allows us to draw an analogy between impact stars and spikes as found both in Forceville's analysis and here, but the sheer size of the points indicate the intensity of the event. These runes are often accompanied by regular stars, which are conventionally used in comics to imply pain, textual indicators, or other accessories intended to emphasize the painful sensation experienced by the character who has suffered a physical blow of sorts.

\subsubsection{Bubbles}

The final type of pictorial runes observed in the comic book series Gea is bubbles, groups of small circles of various sizes. They appear above or around a person's head, indicating temporarily impaired awareness, e.g. in a person waking up, coming around from being unconscious, or in a hallucinatory state (Fig. 12, 9.26.5). There were 39 panels with bubbles in the comic book series ( $0.41 \%$ across 18 volumes).

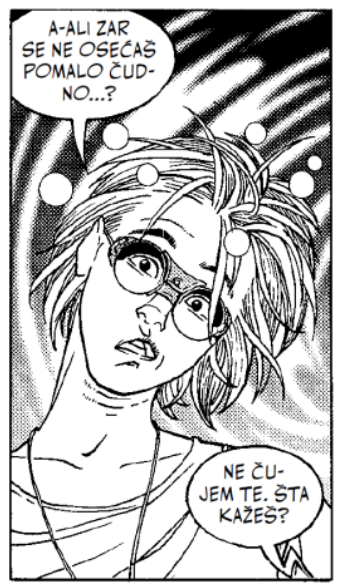

Fig. 12 Bubbles, Gea 9: Sin groma @ 2010 Luca Enoch/Sergio Bonelli Editore

We believe that bubbles are likely to be (at least, etymologically) linked to our bodily experience. Namely, the reason behind the use of bubbles to indicate the above states most probably lies in the fact that our vision is obscured at such times, that is, that we cannot see clearly and are under the impression that we are looking through water as our eyes fill up with tears or we lose focus. When bubbles burst, and we regain full consciousness, the image before our eyes becomes clear again.

\subsection{Rune distribution}

Although our primary goal was to assess the existing rune catalogue and add new runes to it, we will briefly comment on the distribution of runes across separate volumes of the series, given the fact that in the previous section we provided only the total percentages of each runic type within the whole series, i.e. the total number of panels. Tables 1 and 2 summarise our findings using the cells that are conditionally shaded per each rune: the darkest cell indicates the volume with the highest percentage of the rune in question, and the brightest cell denotes the volume with the lowest percentage of the same rune. 
Table 1 Distribution of pictorial runes across volumes: an overview

\begin{tabular}{|c|c|c|c|c|c|c|c|c|c|c|c|c|c|c|c|}
\hline 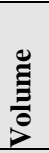 & 胥 & 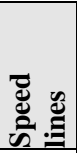 & $\%$ & 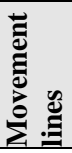 & $\%$ & 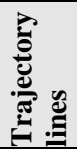 & $\%$ & 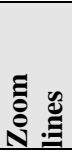 & $\%$ & 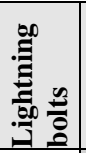 & $\%$ & 冚 & $\%$ & 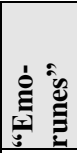 & $\%$ \\
\hline 1 & 584 & 34 & 5.82 & 158 & 27.05 & 10 & 1.71 & 7 & 1.20 & 3 & 0.51 & 6 & 1.03 & 33 & 5.65 \\
\hline 2 & 518 & 42 & 8.11 & 142 & 27.41 & 10 & 1.93 & 5 & 0.97 & 5 & 0.97 & 3 & 0.58 & 40 & 7.72 \\
\hline 3 & 494 & 22 & 4.45 & 82 & 16.60 & 7 & 1.42 & 4 & 0.81 & 2 & 0.40 & 1 & 0.20 & 20 & 4.05 \\
\hline 4 & 502 & 22 & 4.38 & 110 & 21.91 & 6 & 1.20 & 4 & 0.80 & 1 & 0.20 & 0 & 0.00 & 12 & 2.39 \\
\hline 5 & 513 & 41 & 7.99 & 134 & 26.12 & 6 & 1.17 & 3 & 0.58 & 1 & 0.19 & 1 & 0.19 & 28 & 5.46 \\
\hline 6 & 542 & 30 & 5.54 & 177 & 32.66 & 5 & 0.92 & 8 & 1.48 & 2 & 0.37 & 8 & 1.48 & 24 & 4.43 \\
\hline 7 & 553 & 29 & 5.24 & 176 & 31.83 & 6 & 1.08 & 9 & 1.63 & 2 & 0.36 & 3 & 0.54 & 34 & 6.15 \\
\hline 8 & 522 & 11 & 2.11 & 146 & 27.97 & 3 & 0.57 & 3 & 0.57 & 2 & 0.38 & 1 & 0.19 & 39 & 7.47 \\
\hline 9 & 531 & 14 & 2.64 & 118 & 22.22 & 6 & 1.13 & 5 & 0.94 & 0 & 0.00 & 1 & 0.19 & 19 & 3.58 \\
\hline 10 & 552 & 18 & 3.26 & 234 & 42.39 & 4 & 0.72 & 5 & 0.91 & 1 & 0.18 & 0 & 0.00 & 20 & 3.62 \\
\hline 11 & 564 & 27 & 4.79 & 188 & 33.33 & 3 & 0.53 & 10 & 1.77 & 0 & 0.00 & 2 & 0.35 & 9 & 1.60 \\
\hline 12 & 572 & 16 & 2.80 & 185 & 32.34 & 4 & 0.70 & 6 & 1.05 & 0 & 0.00 & 0 & 0.00 & 10 & 1.75 \\
\hline 13 & 525 & 32 & 6.10 & 139 & 26.48 & 3 & 0.57 & 15 & 2.86 & 0 & 0.00 & 0 & 0.00 & 18 & 3.43 \\
\hline 14 & 497 & 27 & 5.43 & 99 & 19.92 & 1 & 0.20 & 4 & 0.80 & 0 & 0.00 & 1 & 0.20 & 2 & 0.40 \\
\hline 15 & 544 & 39 & 7.17 & 127 & 23.35 & 2 & 0.37 & 9 & 1.65 & 0 & 0.00 & 0 & 0.00 & 7 & 1.29 \\
\hline 16 & 513 & 33 & 6.43 & 170 & 33.14 & 1 & 0.19 & 5 & 0.97 & 0 & 0.00 & 0 & 0.00 & 5 & 0.97 \\
\hline 17 & 559 & 31 & 5.55 & 162 & 28.98 & 4 & 0.72 & 1 & 0.18 & 5 & 0.89 & 1 & 0.18 & 19 & 3.40 \\
\hline 18 & 532 & 32 & 6.02 & 127 & 23.87 & 0 & 0.00 & 1 & 0.19 & 0 & 0.00 & 0 & 0.00 & 18 & 3.38 \\
\hline$\sum$ & 9617 & 500 & 5.20 & 2674 & 27.80 & 81 & 0.84 & 104 & 1.08 & 24 & 0.25 & 28 & 0.29 & 357 & 3.71 \\
\hline
\end{tabular}

Table 2 Distribution of pictorial runes across volumes: "emo-runes" breakdown

\begin{tabular}{|c|c|c|c|c|c|c|c|c|c|c|c|c|c|c|c|c|c|c|c|}
\hline$\frac{\text { ㄹ }}{2}$ & 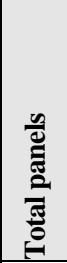 & $\frac{\frac{n}{0}}{\frac{0}{0}}$ & $\%$ & 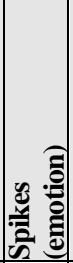 & $\%$ & 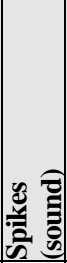 & $\%$ & 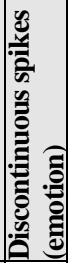 & $\%$ & 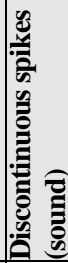 & $\%$ & 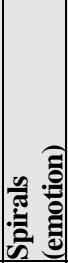 & $\%$ & 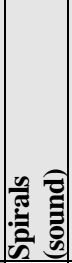 & $\%$ & $\bar{E}$ & $\%$ & $\frac{\frac{y}{0}}{\frac{0}{0}}$ & $\%$ \\
\hline 1 & 584 & 15 & 2.57 & 2 & 0.34 & 7 & 1.20 & 3 & 0.51 & 0 & 0.00 & 11 & 1.88 & 0 & 0.00 & 2 & 0.34 & 0 & 0.00 \\
\hline 2 & 518 & 13 & 2.51 & 5 & 0.97 & 10 & 1.93 & 2 & 0.39 & 6 & 1.16 & 9 & 1.74 & 2 & 0.39 & 8 & 1.54 & 3 & 0.58 \\
\hline 3 & 494 & 6 & 1.21 & 0 & 0.00 & 7 & 1.42 & 1 & 0.20 & 0 & 0.00 & 4 & 0.81 & 1 & 0.20 & 5 & 1.01 & 4 & 0.81 \\
\hline 4 & 502 & 4 & 0.80 & 0 & 0.00 & 5 & 1.00 & 1 & 0.20 & 0 & 0.00 & 1 & 0.20 & 0 & 0.00 & 6 & 1.20 & 0 & 0.00 \\
\hline 5 & 513 & 7 & 1.36 & 3 & 0.58 & 5 & 0.97 & 6 & 1.17 & 3 & 0.58 & 5 & 0.97 & 0 & 0.00 & 2 & 0.39 & 5 & 0.97 \\
\hline 6 & 542 & 13 & 2.40 & 0 & 0.00 & 0 & 0.00 & 3 & 0.55 & 3 & 0.55 & 1 & 0.18 & 0 & 0.00 & 4 & 0.74 & 3 & 0.55 \\
\hline 7 & 553 & 15 & 2.71 & 1 & 0.18 & 5 & 0.90 & 0 & 0.00 & 1 & 0.18 & 2 & 0.36 & 0 & 0.00 & 5 & 0.90 & 11 & 1.99 \\
\hline 8 & 522 & 17 & 3.26 & 1 & 0.19 & 5 & 0.96 & 5 & 0.96 & 3 & 0.57 & 9 & 1.72 & 0 & 0.00 & 3 & 0.57 & 4 & 0.77 \\
\hline 9 & 531 & 2 & 0.38 & 3 & 0.56 & 5 & 0.94 & 5 & 0.94 & 4 & 0.75 & 1 & 0.19 & 0 & 0.00 & 3 & 0.56 & 5 & 0.94 \\
\hline 10 & 552 & 9 & 1.63 & 1 & 0.18 & 5 & 0.91 & 4 & 0.72 & 3 & 0.54 & 0 & 0.00 & 0 & 0.00 & 6 & 1.09 & 0 & 0.00 \\
\hline 11 & 564 & 2 & 0.35 & 1 & 0.18 & 6 & 1.06 & 3 & 0.53 & 3 & 0.53 & 0 & 0.00 & 0 & 0.00 & 2 & 0.35 & 1 & 0.18 \\
\hline 12 & 572 & 2 & 0.35 & 1 & 0.17 & 5 & 0.87 & 2 & 0.35 & 2 & 0.35 & 2 & 0.35 & 0 & 0.00 & 2 & 0.35 & 1 & 0.17 \\
\hline 13 & 525 & 7 & 1.33 & 4 & 0.76 & 1 & 0.19 & 1 & 0.19 & 0 & 0.00 & 4 & 0.76 & 0 & 0.00 & 2 & 0.38 & 0 & 0.00 \\
\hline 14 & 497 & 0 & 0.00 & 0 & 0.00 & 3 & 0.60 & 0 & 0.00 & 1 & 0.20 & 0 & 0.00 & 0 & 0.00 & 2 & 0.40 & 0 & 0.00 \\
\hline 15 & 544 & 2 & 0.37 & 3 & 0.55 & 8 & 1.47 & 1 & 0.18 & 0 & 0.00 & 0 & 0.00 & 0 & 0.00 & 0 & 0.00 & 1 & 0.18 \\
\hline 16 & 513 & 2 & 0.39 & 2 & 0.39 & 5 & 0.97 & 0 & 0.00 & 0 & 0.00 & 0 & 0.00 & 0 & 0.00 & 1 & 0.19 & 0 & 0.00 \\
\hline 17 & 559 & 6 & 1.07 & 6 & 1.07 & 16 & 2.86 & 0 & 0.00 & 6 & 1.07 & 6 & 1.07 & 0 & 0.00 & 1 & 0.18 & 0 & 0.00 \\
\hline 18 & 532 & 10 & 1.88 & 1 & 0.19 & 6 & 1.13 & 1 & 0.19 & 1 & 0.19 & 3 & 0.56 & 0 & 0.00 & 2 & 0.38 & 1 & 0.19 \\
\hline$\sum$ & 9617 & 132 & 1.37 & 34 & 0.35 & 104 & 1.08 & 38 & 0.40 & 36 & 0.37 & 58 & 0.60 & 3 & 0.03 & 56 & 0.58 & 39 & 0.41 \\
\hline
\end{tabular}


The first thing that strikes the reader from the above tables is the number of movement lines, which are the most frequently used of all the runes in Gea. Their numbers vary slightly from volume to volume, but drop below a hundred only on two occasions, 82 in volume 3 and 99 in volume 14, which marks the only two instances where the percentage of these runes per number of panels in a volume drops below 20\%. Another type of runes with a steady number of instances is speed lines, and we can conclude that these two types are the ones most dominantly employed by the artist in the entire series, even though there are certain fluctuations in their use. At the same time, these two types can hardly be compared with the remaining ones, as their usage is certainly conditioned by the static nature of the medium, making them an arguably necessary graphic device in Enoch's arsenal. None of the other runes are present in more than $1.5 \%$ of total panels in the series.

The second observation, and a rather tentative one at that, is related to those pictorial runes typically linked with emotions, or what we would call here "emo-runes", Table 2. These types of runes were conspicuously left out of the artwork in several volumes that were drawn with a greater emphasis on facial features and in a more serious tone. It should be noted that these differences in the tone of the narrative are not too drastic or overly pronounced, yet they can, indeed, be traced over the course of the story. If we take into consideration the five types which are primarily used to indicate different emotions or mental states (droplets, spikes, spirals, twirl, and bubbles), we can observe a drop in the total number of these runes in the second, less light-hearted, part of the series, i.e., 249 instances in volumes 1-9 and 108 instances in volumes 10-18. Also interesting to note is the fact that the artist continues to use spikes to indicate sound even though he relinquishes their use as a device to express or enhance emotions. As far as the statistical analysis of these findings is concerned, we discovered a negative correlation between the volume number and the total number of emotion runes $[\mathrm{r}=-.608, \mathrm{n}=18, \mathrm{p}=.007]$. The change is most obvious for twirls $[\mathrm{r}=-.653, \mathrm{n}=18, \mathrm{p}=.003]$, whose number decreases significantly in the latter part of the series. The only remaining correlations we could observe were negative correlations between the volume number and the total number of trajectory lines $[\mathrm{r}$ $=-.877, \mathrm{n}=18, \mathrm{p}=.000]$ and impact stars $[\mathrm{r}=-.498, \mathrm{n}=18, \mathrm{p}=.035]$. Such a tendency could also perhaps be contributed to the modification of the artist's rendering of drawings due to the changing tone of the narrative and the decreased use of runes for comic effect.

Finally, the distribution of runes in Gea depends significantly on the background drawn in each of the panels. The comic book series is rendered in black and white, and Enoch uses a variety of different styles, ranging from highly detailed backgrounds to plain white spaces behind the characters. Bearing this in mind, one can easily observe how more detailed backgrounds somewhat limit the use of runes. The artist is also prone to using dot patterns to fill up larger spaces in the background, which further complicates the situation. On the other hand, a plain white background allows the artist to use a plethora of runes in a single panel.

\section{CONCLUSIONS}

We set out to enrich Forceville's catalogue of pictorial runes, and we have managed to add five types to the original six, based only on one series of comics - this implies that it is probably possible to expand this catalogue further by using additional corpora. The corpora should include as many different traditions of comics, so as to reflect the variations 
between these traditions when it comes to expressing facets of meaning usually conveyed by means of runes. This, in turn, might lead towards creating a "dictionary" of runes, which would involve different catalogues. Our analysis seems to imply that the identified pictorial runes are, indeed, indexical and not symbolic signs. One last point of interest is the likely important pattern of distribution of runes across the entire series, which indicates the tendency towards disproportionate use of all those rune types related to motion in comparison with the other types, as well as the reduction in the use of emotion runes due to the tone of the narrative. Further investigations, desirably of other comics traditions, or involving a diachronic approach (e.g. Pederson and Cohn 2016), could perhaps provide more evidence to the above claims.

Acknowledgement: The study was supported by the project no. 179013, sponsored by the Ministry of Education, Science, and Technological Development of the Republic of Serbia, and implemented at the University of Niš. An early version of this study was presented at the $4^{\text {th }} U K$ Cognitive Linguistics Conference (King's College London, 10-12 July 2012). The authors would like to extend their gratitude to the anonymous reviewers for providing very constructive comments and suggestions.

\section{REFERENCES}

Bateman, J. and Wildfeuer, J., (2014), “A Multimodal Discourse Theory of Visual Narrative”. Journal of Pragmatics 74: pp. 180-208. doi: 10.1016/j.pragma.2014.10.001.

Bounegru, L. and Forceville, C., (2011), "Metaphors in Editorial Cartoons Representing the Global Financial Crisis", Visual Communication 10, Vol. 2: pp. 209-229. doi: 10.1177/1470357211398446.

Bridgeman, T., (2005), "Figuration and Configuration: Mapping Imaginary Worlds in BD", In: Forsdick, C., Grove, L., and McQuillan, L. (eds.), The Francophone Bande Desinée, pp. 115-136, Rodopi, Amsterdam.

Cohn, N., (2003), Early Writings on Visual Language, Emaki Productions, Carlsbad, CA.

Cohn, N., (2007), “A Visual Lexicon”, Public Journal of Semiotics 1, Vol. 1: pp. 53-84.

Cohn, N., (2010), "Japanese Visual Language: The Structure of Manga”, In: Johnson-Woods, T. (ed.), Manga: An Anthology of Global and Cultural Perspectives, pp. 187-203, Continuum Books, New York.

Cohn, N., (2012a), "Comics, Linguistics, and Visual Language: The Past and Future of a Field.” In: Bramlett, F. (ed.), Linguistics and the Study of Comics, pp. 92-118, Palgrave MacMillan, New York.

Cohn, N., (2012b), Structure, Meaning, and Constituency in Visual Narrative Comprehension, Doctoral dissertation, Tufts University.

Cohn, N., (2013), The Visual Language of Comics: Introduction to the Structure and Cognition of Sequential Images, Bloomsbury Publishing, London.

Cohn, N., and Ehly, S., (2016), "The Vocabulary of Manga: Visual Morphology in Dialects of Japanese Visual Language". Journal of Pragmatics 92: pp. 17-29. doi: 10.1016/j.pragma.2015.11.008.

Cohn, N. and Maher, S., (2015), "The Notion of the Motion: The Neurocognition of Motion Lines in Visual Narratives”, Brain Research 1601: pp. 73-84. doi: 10.1016/j.brainres.2015.01.018.

Eerden, B., (2009), "Anger in Asterix: The Metaphorical Representation of Anger in Comics and Animated Films”. In: Forceville, C. and Urios-Aparisi, E. (eds.), Multimodal Metaphor, pp. 243-264, Mouton de Gruyter, Berlin/New York.

Eisner, W., (1985/2008), Comics and Sequential Art, W. W. Norton \& Company, New York/London.

Engelhardt, Y., (2002), The Language of Graphics: A Framework for the Analysis of Syntax and Meaning in Maps, Charts and Diagrams, ILLC/University of Amsterdam, Amsterdam.

Forceville, C., (1994), "Pictorial Metaphor in Advertisements", Metaphor and Symbolic Activity 9, Vol. 1: pp. 1-29. doi: 10.1207/s15327868ms0901_1.

Forceville, C., (1996), Pictorial Metaphor in Advertising, Routledge, London.

Forceville, C., (2005), "Visual Representations of the Idealized Cognitive Model of Anger in the Asterix Album La Zizanie", Journal of Pragmatics 37: 69-88. doi: 110.1016/j.pragma.2003.10.002.

Forceville, C., (2006), "Non-verbal and Multimodal Metaphor in a Cognitivist Framework: Agendas for Research", In: Kristiansen, G., Achard, M., Dirven, R. and Ruiz de Mendoza Ibáñez, F. (eds.), Cognitive 
Linguistics: Current Applications and Future Perspectives, pp. 379-402), Mouton de Gruyter, Berlin/New York.

Forceville, C., (2008), "Metaphor in Pictures and Multimodal Representations", In: Gibbs, Jr., R. (ed.), The Cambridge Handbook of Metaphor and Thought, pp. 462-482, Cambridge University Press, Cambridge.

Forceville, C., (2011), "Pictorial Runes in Tintin and the Picaros", Journal of Pragmatics 43: pp. 875-890. doi: 10.1016/j.pragma.2010.07.014.

Forceville, C. and Urios-Aparisi, E. (eds.), (2009a), Multimodal Metaphor, Mouton de Gruyter, Berlin/New York.

Forceville, C. and Urios-Aparisi, E., (2009b), "Introduction", In: Forceville, C. and Urios-Aparisi, E. (eds.), Multimodal Metaphor, pp. 3-17, Mouton de Gruyter, Berlin/New York.

Gasca, L. and Gubern, R., (2001), El discurso del comic, Catedra, Madrid.

Gibbs, Jr., R., (2006), Embodiment and Cognitive Science, Cambridge University Press, New York.

Gubern, R., (1972), El lenguaje de los comics, Peninsula, Barcelona.

Hünig, W.K., (1974), Strukturen des comic strip, Olms, Hildensheim.

Johnson, M., (1987), The Body in the Mind: The Bodily Basis of Meaning, Imagination and Reason, University of Chicago Press, Chicago.

Kennedy, J., (1982), "Metaphor in Pictures”, Perception 11: pp. 589-605.

Koch, W.A., (1971), Varia semiotica, Olms, Hildensheim.

Kövecses, Z., (2010), Metaphor: A Practical Introduction, 2nd ed, Oxford University Press, Oxford.

Lakoff, G., (1987), Women, Fire, and Dangerous Things: What Categories Reveal About the Mind, University of Chicago Press, Chicago.

Lakoff, G., (1993), “The Contemporary Theory of Metaphor”, In: Ortony, A. (ed.), Metaphor and Thought, 2nd ed., pp. 202-251, Cambridge University Press, Cambridge.

Lakoff, G. and Johnson, M., (1980), Metaphors We Live By, University of Chicago Press, Chicago.

Lim, V.F., (2006), "The Visual Semantics Stratum: Making Meanings in Sequential Images”, In: Royce, T. and Bowcher, W. (eds.), New Directions in the Analysis of Multimodal Discourse, pp. 195-214, Lawrence Erlbaum Associates, New Jersey.

McCloud, S., (1993), Understanding Comics: The Invisible Art, Harper Collins, New York.

McCloud, S., (2006), Making Comics: Storytelling Secrets of Comics, Manga and Graphic Novels, Harper, New York.

Ojha, A., Forceville, C., and Indurkhya, B., (2013), "Pictorial runes and their role in depicting emotions". Paper presented at Researching and Applying Metaphor Seminar on Metaphor, Metonymy and Emotions. Adam Mickiewicz University, Poznań, May 2013.

Pederson, K., and Cohn, N., (2016), "The Changing Pages of Comics: Page Layouts Across Eight Decades of American Superhero Comics". Studies in Comics 7, Vol 1: pp. 7-28. doi:10.1386/stic.7.1.7_1.

Potsch, E., and Williams, R.F., (2012), "Image Schemas and Conceptual Metaphor in Action Comics." In: Bramlett, F. (ed.), Linguistics and the Study of Comics, pp. 13-36, Palgrave MacMillan, New York.

Saraceni, M., (2000), Language Beyond Language: Comics as Verbo-Visual Texts, Doctoral dissertation, University of Nottingham

Saraceni, M., (2003), The Language of Comics, Routledge, London/New York.

Shinohara, K. and Matsunaka, Y., (2009), "Pictorial Metaphors of Emotion in Japanese Comics", In: Forceville, C. and Urios-Aparisi, E. (eds.), Multimodal Metaphor, pp. 265-293, Mouton de Gruyter, Berlin/New York.

Stainbrook, E.J., (2003), Reading Comics: A Theoretical Analysis of Textuality and Discourse in the Comics Medium, Doctoral dissertation, University of Pennsylvania

Stamenković, D. and Tasić, M., (2014), "The Contribution of Cognitive Linguistics to Comics Studies", The Balkan Journal of Philosophy 6, Vol. 2: pp. 155-162. doi: 10.5840/bjp20146221.

Sweetser, E., (1991), From Etymology to Pragmatics: Metaphorical and Cultural Aspects of Semantic Structure, Cambridge University Press, Cambridge.

Tan, E.S., (2001), "The Telling Face in Comic Strip and Graphic Novel”, In: Baetens, J. (ed.), The Graphic Novel, pp. 31-46, Leuven University Press, Leuven.

Van Eunen, T., (2007), Angst, woede, liefde en trots: De visuele representatie van emoties in Asterix en Donald Duck, Master's thesis, Universiteit van Amsterdam.

Walker, M., (1980), The Lexicon of Comicana, Comicana, Inc., Port Chester, NY. 


\section{COMIC BOOKS}

Enoh, L., (2010), Gea 1: Zaštitnica, Darkwood, Beograd.

Enoh, L., (2010), Gea 2: Dionisova povorka, Darkwood, Beograd.

Enoh, L., (2010), Gea 3: Priče o duhovima, Darkwood, Beograd.

Enoh, L., (2010), Gea 4: Majka nasilja, Darkwood, Beograd.

Enoh, L., (2010), Gea 5: Nerov put, Darkwood, Beograd.

Enoh, L., (2010), Gea 6: Bauk, Darkwood, Beograd.

Enoh, L., (2010), Gea 7: Klajvov krst, Darkwood, Beograd.

Enoh, L., (2010), Gea 8: Gde voda teče, Darkwood, Beograd.

Enoh, L., (2011), Gea 9: Sin groma, Darkwood, Beograd.

Enoh, L., (2011), Gea 10: Uljez, Darkwood, Beograd.

Enoh, L., (2011), Gea 11: Poludeli zaštitnik, Darkwood, Beograd.

Enoh, L., (2011), Gea 12: Knjiga razotkrivenih tajni, Darkwood, Beograd.

Enoh, L., (2011), Gea 13: Pucanje pečata, Darkwood, Beograd.

Enoh, L., (2011), Gea 14: Pad kapije, Darkwood, Beograd.

Enoh, L., (2011), Gea 15: Najezda stranaca, Darkwood, Beograd.

Enoh, L., (2011), Gea 16: Zima rata, Darkwood, Beograd.

Enoh, L., (2011), Gea 17: Doba surovosti, Darkwood, Beograd.

Enoh, L., (2011), Gea 18: Kuća pevova, Darkwood, Beograd.

\section{ISTRAŽIVANJE SLIKOVNIH RUNA U STRIP SERIJALU GEA LUKE ENOH}

Oslanjajući se na rad Forsvila (Forceville 2005, 2006, 2011), koji istraživanju stripa pristupa uglavnom iz lingvističke perspektive, autori razmatraju slikovne rune kao poseban oblik vizuelnih informacija koje možemo naći u stripu. Kao što Kenedi (Kennedy 1982) tvrdi, slikovne rune predstavljaju grafička sredstva upotrebljena na slikama u funkciji modifikacije doslovnog prikaza predmeta, sa namerom da se prenesu određeni aspekti tih objekata koje bi inače bilo teško doslovce prikazati na slici. U stripu se one, između ostalog, najčešće koriste kako bi dočarale različita emotivna stanja, poput besa, straha, bola ili čuđenja, i pokazale smer i pravac kretanja nekog predmeta. Na osnovu istraživačkog modela koji je Forsvil predstavio 2011. godine, rad se bavi identifikacijom i kategorizacijom slikovnih runa u popularnom italijanskom strip serijalu Gea, sa ciljem da se gorenavedeni metod potvrdi i pronađu rune kojima bi se upotpunio već postojeći katalog. Uz to, prezentovani su i dokazi da novopronadene rune predstavljaju indeksne, a ne simbolicke znakove. U radu se takođe ukratko razmatra i distribucija runa na nivou celog serijala.

Ključne reči: slikovne rune, vizuelni jezik, studije stripa, katalog runa, metafora, metonimija 